\title{
FUZZY AHP METHOD, UNCERTAINTY AND DECISION-MAKING
}

\author{
Buchmeister, B.; Polajnar, A.; PandzA, K. \& Kremluak, Z.
}

Abstract: In decision making under uncertainty, risk analysis aims at minimising the failure to achieve a desired result. In the paper our original method of uncertainty estimation is presented. Each problem involving uncertainty and consecutive appearing risk is divided into identified categories and factors of uncertainty. The basic method used in the numerical part of the evaluation is the two-pass Fuzzy Analytic Hierarchy Process (applied: first for the importance and second for the uncertainty of risk factors). The process is based on the determination of relations between particular risk categories and factors. The estimates are derived from pairwise comparison of factors belonging to each category. By using fuzzy numbers the consideration of possible errors of the estimator is taken into account. In the following stages the interval results obtained by this method are used for calculating the integral uncertainty value, which, in comparison with the boundary value, defines the risk of the process in question. Based on the "Uncertainty - Importance" relations special $A B C$ focus diagrams are created. These diagrams serve for the classification of uncertainty factors, which provides a decision making part of the systemic approach.

Key words: uncertainty, risk, estimation, fuzzy AHP method, systematic approach
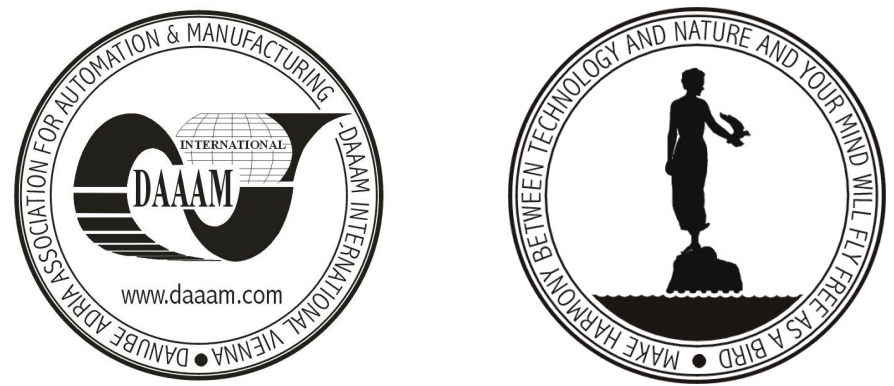

Authors' data: Associate Prof. Dr. Buchmeister B.[orut]*, Prof. Dr. Polajnar A.[ndrej]*, Assistant Prof. Dr. Pandza K[rsto ${ }^{* *}$, Dr. Kremljak Z[vonko]*** *University of Maribor, Faculty of Mechanical Engineering, Maribor, Slovenia, **Leeds University Business School, Leeds, United Kingdom, ***Ministry of the Economy, Government of the Republic of Slovenia, borut.buchmeister@uni-mb.si, andrej.polajnar@uni-mb.si,k.pandza@leeds.ac.uk,zvonko.kremljak@s5.net

This Publication has to be referred as: Buchmeister, B.; Polajnar, A.; Pandza, K. \& Kremljak, Z. (2006). Fuzzy AHP Method, Uncertainty and Decision-Making, Chapter 08 in DAAAM International Scientific Book 2006, B. Katalinic (Ed.), Published by DAAAM International, ISBN 3-901509-47-X, ISSN 1726-9687, Vienna, Austria DOI: $10.2507 /$ daaam.scibook.2006.08 